\title{
Epifania twarzy czy iluzja maski? O zmaganiu się człowieka w ujęciu filozofii dramatu Józefa Tischnera
}

\begin{abstract}
Inga Mizdrak, Epifania twarzy czy iluzja maski? O zmaganiu się człowieka w ujęciu filozofii dramatu Józefa Tischnera [Facial epiphany or mask illusion? About the struggle of man in terms of the Józef Tischner's philosophy of drama]. „Przestrzenie Teorii” 36. Poznań 2021, Adam Mickiewicz University Press, pp. 257-271. ISSN 1644-6763. DOI 10.14746/pt.2021.36.15.

The aim of the article is to present human issues in the context of the face and the mask as its negative. This is to bring us closer to a better diagnosis of the human condition today and the changes that can be articulated on its basis. Both the face and the mask are multi-context, and any attempt to define them encounters a number of difficulties. In Józef Tischner's philosophy of drama, the face is a condition for the essence of the meeting. On the other hand, the mask, as an appearance and falsification of the truth of the face, is placed in the ambiguous perspective of hiding, concealing, mystifying or obscuring or obscuring the image of the face. Thanks to the face, man is somehow "at home", and in the bonds of the mask he is somewhat "out of place", he is lying. The face is relational and the mask is reactionary. Inquiries about whether the face brings closer and reveals the naked being of a human intensified questions about the nature of the face itself and whether it is possible to reach the pure phenomenon of the face as such. Both the face and the mask reveal important moments in the characteristics of a human being as a dramatic being, in which questions about meaning, identity, freedom and responsibility, as well as what is "between" I and You, gain in intensity and imply new attempts to reveal who is a human.
\end{abstract}

KEYWORDS: dialogue, face, mask, relation, identity, drama

\section{Wprowadzenie}

W filozoficznym sporze o człowieka (jego kondycję, tożsamość, podmiotowość oraz podstawowe właściwości) istotną rolę odgrywa filozofia dialogu i to nie tylko przez jej walory analityczne, lecz zwłaszcza przez różnorodny wymiar opisu doświadczenia człowieka jako bytu relacyjnego. Głównym paradygmatem, wokół którego myśliciele rozwijają swe koncepcje, jest spotkanie z Ty drugiego (Martin Buber), z Innym (Emmanuel Lévinas, Józef Tischner). Człowiek jawi się jako byt odniesiony do drugiego, w określony sposób uczestniczy w byciu drugiego, a poprzez niego coraz bardziej może wnikać w poznanie i rozumienie samego siebie. Różnice w pojmowaniu relacji z drugim człowiekiem, typowe dla przedstawicieli tego nurtu (np. ujmowanie relacji Ja-Ty przez Bubera, Toż-Samego - Innego przez Lévinasa czy Pytajacego i Zapytanego przez Tischnera), odsyłają do wspólnych py- 
tań o istotę człowieka i fundamentalnych kwestii etyczno-aksjologiczno-egzystencjalnych. Wspólnego gruntu w myśleniu można upatrywać na płaszczyźnie poszukiwania wartości konkretnego podmiotu, niezbywalnego charakteru Ja, ale także udramatycznionej kategorii „pomiędzy”, w której jest rozpatrywana cała rozgrywająca się historia relacji Ja-Ty. Przy czym relacyjność jest rozpatrywana w kontekście symetryczności lub asymetryczności, zwrotności bądź niezwrotności, aktywności i dynamiczności, egocentryczności i pasywności czy monologiczności i dialogiczności.

Pośród znaczących myślicieli reprezentujących nurt filozofii dialogu, takich jak Ferdinand Ebner, Martin Buber, Franz Rosenzweig czy Emmanuel Lévinas, ważny głos w dyskusji nad człowiekiem zabiera Józef Tischner, którego bogata spuścizna filozoficzna nadal inspiruje współczesną humanistykę, odznaczając się wieloma implikacjami etycznymi, metafizycznymi, psychologicznymi, a nawet pedagogicznymi. Rozważania Tischnera wydają się dziś nadal aktualne - ze względu nie tylko na nośność samego problemu spotkania, lecz także na pojemność kategorii dramatu, której nadał on oryginalną warstwę znaczeniową i ukazał w nowym świetle jej konsekwencje dla głębszego rozumienia relacji. Udramatycznienie spotkania stało się niejako filozoficzną wizytówką Tischnera. W dialogice Bubera i teorii epifanii twarzy Lévinasa kategoria dramatu wprost nie występuje. Jednakże Tischner, odwołując się do obu myślicieli, z pewnością wyczuwał problem dramatu obecny zarówno w koncepcji „pomiędzy” Martina Bubera, jak i w imperatywie etycznym płynącym z twarzy Innego u Lévinasa.

Słynne Buberowskie rozróżnienie na świat Ja-To oraz Ja-Ty wykrystalizowuje również sposób rozumienia sfery „pomiędzy”. W odniesieniu Ja-To mamy domykalność, zamkniętość i dokonanie bytu. Świat To niejako unieruchamia byt. Twardnieje on w zamkniętym odcinku czasu, jest zależny od czaso-przestrzeni i staje się dla niej pustym, skostniałym przedmiotem. Przeciwna sytuacja występuje w świecie Ty, które jest otwartościa, niezakończonym i niedomykalnym procesem aktualizującym się w teraz, „przeźroczystością w przestrzeni i czasie”. W świecie Ty podmiot staje się czystym aktem, podmiotowym „kims””, kto jest porządkiem świata. Sfera „pomiędzy” jest więc relacją istnień, istotowym odniesieniem człowieka do drugiego, a jej wielorakie odcienie ogniskują się w aktywnej dialogice procesu relacji i wymagają ciagłego nasłuchiwania drugiego w jego byciu, gdyż „sfera międzyludzkiego to sfera wzajemnego bycia naprzeciw”. Owo „naprzeciw”, tak charakterystyczne w opisie relacji, jest nastrojeniem, gotowością wejścia w horyzont „Ty”, tego, co ważne, autentyczne i twórcze.

${ }^{1}$ M. Buber, Ja i Ty. Wybór pism filozoficznych, Warszawa 1992, s. 141. 
Cenną intuicję można odnaleźć u Adama Hernasa, który w tym kontekście pisze: „Oddzielenie i odstęp, uwolnienie się z ucisku, odskok, zajęcie pozycji wobec i naprzeciw, a zatem w pierwszej relacji, polega na zrobieniu wolnego miejsca, na ustanowieniu przestrzeni «między», w której ludzkie bycie może się zaprezentować jako podmiot i osoba. Dopiero z tej odległości podmioty stają się dla siebie widoczne"2.

Dla Lévinasa relacja międzyludzka jest istotowo niesyntetyzowalna i nie musi być symetryczna, ponieważ „w relacji międzyosobowej nie chodzi o to, by myśleć razem mnie i innego, lecz być twarzą w twarz. Prawdziwa jedność lub prawdziwe razem nie jest wyrazem syntezy, lecz razem twarzą w twarz" ${ }^{3}$. Sam Inny jest radykalnie inny, nieuchwytny w gruncie rzeczy w swej podmiotowości, wymyka się poznaniu, pozostaje tajemnica. Sama zaś twarz Innego jest akontekstowa. Drugi nie jest dany w kontekście. Jego twarz ,jest sensem ze względu na nią samą” i „nie może stać się treścią którą objęłaby nasza myśl; jest niezawieralnościa, prowadzi nas poza”4. Lévinas nie odrywa „ja” od życia; przeciwnie - koncentruje się na ,ja”, „które zostaje wtopione w życie, przeżywane i "zamieszkane w innym» (lived with the other). Takie «ja» odrzuca subiektywne i egoistyczne «umiłowanie» samego siebie. Odchodzi ono od samego siebie, aby wziąć odpowiedzialność za innych"5. Mowa twarzy rozpoczyna każdorazowo nową historię dyskursu, w której odpowiedź dana drugiemu wkracza w pole autentycznej relacji, a sama odpowiedzialność nie jawi się li tylko jako odpowiadanie na wezwanie, lecz odpowiadanie za drugiego. Mowa twarzy drugiego konstytuuje się, zanim zrodzi się dialog. Dla Lévinasa to „diakonia jest przed wszelkim dialogiem”, a zatem spełnienie imperatywu etycznego, służenie drugiemu, spełnienie prośby twarzy drugiego, a prośba ta ma nakazowy i niekoniecznie zwrotny charakter. Twarz drugiego wzywa, a czy jego twarz odpowie z kolei na wezwanie mnie samego, to wedle Lévinasa leży w polu jego wolności. Lévinas przerzuca ciężar odpowiedzialności na podmiot widzący twarz drugiego, a nie prezentujący własna. Epifania twarzy płynie ze strony drugiego, bo to ona objawia mnie samemu to, co powinienem względem niego zrobić. Lévinas uzasadnia to tym, iż „jestem odpowiedziany za całą odpowiedzialność, która odpowiada za wszystkich innych i za wszystko u innych, nawet za ich odpowiedzialność””. Totalność odpowiedzialności koncentruje się w „Ja”,

\footnotetext{
${ }^{2}$ A. Hernas, Czas i obecność, Kraków 2005, s. 222.

${ }^{3}$ E. Lévinas, Etyka i Nieskończony, Kraków 1985, s. 46.

${ }^{4}$ Ibidem, s. $49-50$.

${ }^{5}$ J. Wróbel-Best, W kręgu (własnych) słów Emmanuela Lévinasa. Rozmowa na temat ludzkiej egzystencji, Houston 2016, s. 47.

${ }^{6}$ E. Lévinas, op. cit., s. 55.

${ }^{7}$ Ibidem, s. 56.
} 
bowiem ono ma „zawsze większą odpowiedzialność niż wszyscy inni”, a to „brzemię jest najwyższą godnością tego, co jedyne. Niezastapionym «ja» jestem tylko o tyle, o ile jestem odpowiedzialny. Mogę zastapić wszystkich, ale nikt nie może zastapić mnie"8.

Buber i Lévinas, inspirujący Tischnera, wprowadzają elementy, które zainicjowały jego własne przemyślenia, sytuując podmioty poza samotnością bycia. Sam byt ludzki jawi się zrazu jako relacyjny i mimo iż jego swoista „monadyczność” przejawia się w jego inności, to jednak jest odniesiona do dialogiczności i otwiera ją na szerszą perspektywę, w której zjawia się drugi, a wówczas całe odniesienie nabiera zupełnie innej jakości, nowego kształtu i wiedzie przez meandry dramatu, w którym analogia do Kierkegaardowskiego „albo albo” odsłania horyzont zbawienia lub potępienia.

Niniejszy artykuł nie zmierza do całościowej definicji twarzy czy ludzkiej tożsamości, ale stanowi próbę dookreślenia fenomenu twarzy w celu przedzierania się do zagadki człowieka i jej fundamentalnych aspektów. Tezą niniejszych rozważań jest stwierdzenie, iż twarz jako kategoria wieloznaczna wraz z jej rozmaitymi modi udramatycznia samą relację, ale dzięki temu wyjawia się sens prawdy bycia człowieka w świecie i jego ziemskiej wędrówki.

\section{Ja człowieka uczestniczące $w$ dramacie}

Józef Tischner w wykładni pojęcia dramatu jako podstawowej kategorii swego myślenia o człowieku ukazuje źródło spojrzenia nie tylko na egzystencjalny kontekst jego sposobu bycia w świecie, lecz także na relację do drugiego. Spotkanie jako relacja zrazu jest i pozostaje dramatyczne, ponieważ jego rozwój, kierunek i cel są nieprzewidywalne. Stające naprzeciw siebie podmioty wyłaniają się z różnych kontekstów, inaczej myślą i przeżywają świat, a ich wolność, na przecięciu której się spotykaja, zawiera w sobie potencjalność zarówno jedności, jak i rozłamu, wzniosłości albo prymitywności, koherencji albo rozdzielności. Dramat więc staje się nie tylko korzeniem wszelkich relacyjnych styków, lecz także w gruncie rzeczy horyzontem spełnienia bądź niespełnienia człowieka. Dramat i wolność, sprzężone i splecione $\mathrm{w}$ relacji dwóch podmiotów, tętnia, nadając relacji specyficzny rys określania siebie względem wartości.

Pojęcie dramatu ma wielorakie odniesienia i nie wyczerpuje się jedynie w odesłaniu do samej jednostki oraz jej zakorzenienia w świecie. Dramat bowiem gdzieś się rozgrywa, gdzieś wydarza, ma swój rezonans, rytm,

${ }^{8}$ Ibidem, s. 57. 
dynamikę. Jest niejako pulsującym ogniwem relacji, tego, co wydarza się „pomiędzy”, a zarazem staje się twórczym spełnieniem wolności. Tischner już na samym początku Filozofii dramatu upomina się o reaktywację pojęcia dramatu w całym jego ciężarze gatunkowym, co oznacza, iż tu upatruje klucza do zagadki człowieka i kluczem tym chce ją rozjaśnić. Nie czyni tego od strony teoretycznego opisu, lecz próbuje wniknać w samo doświadczenie relacji, kreśląc własną wizję człowieka jako istoty dramatycznej, czyli de facto odniesionej zawsze do Innego (człowieka lub Boga). Dramat w logice ludzkiego losu wskazuje między innymi na intencjonalno-dialogiczne możliwości, ale są one w rękach ludzkiej wolności, która je w swoisty sposób ukonstytuuje. Dlatego Tischner nigdy nie odrywa pojęcia dramatu od człowieka, lecz mocno podkreśla jego uczestnictwo, zakorzenienie i życie w dramacie i na sposób dramatyczny. Człowiek jest podmiotem dramatu, ponieważ w zasięgu jego wolności coś ze swoim życiem robi, jakimś się staje i w określony sposób kształtuje swój los. Tischner rozszerza dyskurs w obrębie całej filozofii o perspektywę dramatyczna, ponieważ „filozofia dramatu nie może stać na zewnątrz ludzkiego dramatu, jako lustrzane odbicie, lecz musi być jego integralnym składnikiem. Myśląc o ludzkim dramacie zguby i ocalenia, filozofia sama staje przed tymi dwiema możliwościami - może siebie zatracić lub może siebie potwierdzić"’.

Pojęcie dramatu, tak podstawowe dla Tischnera, ukazuje człowieka jako istotę zmagającą się, ale też i samą filozofię jako drogę zmagania się z podstawowymi pytaniami o człowieka i samą siebie. Co bliżej oznacza owo zmaganie się człowieka i o co lub z czym jednostka się zmaga? $\mathrm{Z}$ kim lub o kogo się zmaga i w jakim celu się zmaga? Biorąc pod uwage analizy Tischnera, zmaganie się człowieka przybiera różne formy, ma odmienną amplitudę i biegnie w wielu kierunkach. Istotne jest jednak nie tylko i nie tyle samo zmaganie się, co punkt odniesienia: drugi człowiek, który również jest postawiony w sytuacji zmagania się o siebie, własną tożsamość i który tak samo stoi w dramatycznej relacji do innych. Wizja Tischnera nie jest jednak nacechowana pesymizmem uciemiężonej egzystencji ludzkiej, lecz stale wychylona ku nadziei, miłości, prawdzie i dobru, a owo zmaganie się to nieustanny ruch wolności i rozpostarcie między dobrem a złem, zgubą lub ocaleniem. Ja i Ty mogą nieść w sobie zalążki „zbawienia” lub „potępienia”, ale dopiero w spotkaniu przybiora określony kształt. Stąd tak ważny dla Tischnera moment dramatu nie kończy, lecz właśnie każdorazowo rozpoczyna na nowo historię Ja i Ty, w której może pojawić się wszystko.

${ }^{9}$ J. Tischner, Filozofia dramatu, Kraków 2006, s. 8. 


\section{Twarz i maska: w poszukiwaniu prawdy człowieka}

W precyzacji i tropieniu tożsamości człowieka Tischner kieruje swa uwagę na fenomen twarzy, ponieważ to w niej może „przeglądać się” drugi, to dzięki niej relacja nabiera swoistego charakteru, to przez nia ,przechodzą" rozmaite modi osobowości i ogniskują w niej i „na niej” stany emocjonalne oraz uczuciowe danego człowieka. Tischnera zajmuje jednakże nie tyle twarz z jej fizjologiczno-psychologicznymi odniesieniami, ile raczej prawda bycia człowieka objawiajacca się w twarzy, która „objawia się jako dar horyzontu agatologicznego - horyzontu, w którym dobro i zło przybierają formę dramatu, a dramat zapowiada możliwość tragedii lub zwycięstwa człowieka"10.

Horyzont agatologiczny wskazuje na nieobojętny charakter twarzy. Istnieje bowiem swoisty aktywny stosunek człowieka do wartości dobra i zła, a „logos twarzy to sposób, w jaki człowiek przezwycięża perspektywę tragiczności"11 i w jaki odnosi się do własnego oraz cudzego losu. Zajmowane stanowisko względem wartości dobra i zła niejako „odbija się” w/na twarzy, a w przypadku egzystencjalnego stosunku człowieka do własnego tragizmu może wznieść się na pułap patosu egzystencjalnego, który z jednej strony odsyła do doznawanego bólu, trudu, ciężaru, a z drugiej zwraca uwagę na sposób ich pokonywania. Tischner sądzi, iż „śledząc przemiany patosu egzystencjalnego, śledzimy twarz i jej dzieje, śledzimy ujawnioną przez dramat prawdę człowieka"12.

W Filozofii dramatu Tischner do opisu twarzy przedziera się kolejno przez analizę zasłony i maski. Myśliciel chce najpierw zdefiniować przez nie to, czym twarz na pewno nie jest. Tu jednak rodzą się interpretacyjne kłopoty, gdyż Tischner oba negatywy twarzy w kontekście poszukiwania odpowiedzi na pytanie o tożsamość człowieka potraktował dość pobieżnie, artykułując jedynie te ich aspekty, które miały uwypuklić określone rodzaje fałszu czy iluzji. Wydaje się, iż w opisie Tischnera wiele pytań pozostaje nadal otwartych, a ich stawianie nadal zyskuje na sile. Interpretacyjne trudności piętrzą się między innymi na bazie takich pytań, jak: co objawia twarz, a co ukazuje maska?, czy twarz rzeczywiście odsłania tożsamość ja?, czy maska rzeczywiście „maskuje” twarz?, czy twarz pod maska jest nadal tym, czym jest?, czym jest „zamaskowana” twarz, a czym jest „twarz” maski?, czy maska potrzebuje twarzy, by spełniać swą funkcję?, a czy istnieje twarz bez jakiejkolwiek maski?, w jakim horyzoncie myślimy twarz, a w jakim możemy odkrywać istotę maski?, i czy za zdefiniowaną maską kryje się

\footnotetext{
${ }^{10}$ Ibidem, s. 64.

${ }^{11}$ Ibidem, s. 64.

${ }^{12}$ Ibidem, s. 65.
} 
naga twarz?, czy istnieje możliwość dotarcia do nagości twarzy? Te pytania nie wyczerpują złożonej problematyki twarzy, aczkolwiek odsyłają do coraz wnikliwszej analityki ,ja” i prowokują kolejne kwestie do rozstrzygnięcia.

Co znaczy bliżej stwierdzenie Tischnera, iż kiedy spotykamy Innego, spotykamy go „w jego twarzy”? Czy w pytaniu tym nie kryje się założenie o prymarnym charakterze prawdy bycia człowieka zawartej w twarzy drugiego? Czy rzeczywiście twarz innego „mówi” prawdę o nim i ją objawia? Na czym miałaby polegać „prawda twarzy” i jaka rolę odgrywa w relacji do drugiego? Jaką perspektywę odsłania twarz innego, a jaką jego „beztwarzowość"?

Radykalność tezy o spotkaniu drugiego „w jego twarzy” nastręcza wiele trudności, ponieważ interpretacja i koncepcja twarzy nie zostały przez Tischnera domyślane. To, co Tischner zarysował, daje pewną intuicję, ale zostawia czytelnika z wieloma watpliwościami i pytaniami. Tischner odwołuje się do Lévinasowskiej epifanii twarzy, by następnie zarysować własny punkt widzenia. Wskazuje za Lévinasem najpierw na ten moment spotkania, w której twarz unaocznia się jako dana. Twarz w spotkaniu jest nie tylko daną faktyczną (spotkaną w czasie i przestrzeni) czy fizjologiczna (o określonej strukturze, kształcie, fizjonomii), lecz także daną drugiemu epifania - objawieniem tego, kim jest inny. Gdy staje się twarzą w twarz z drugim, z pewnościa ,jest to jednocześnie włączenie się w porządek tajemnicy, która nie przestaje mnie fascynować swą niepoznawalnościa, lecz z którą zadzierzgnąłem w spotkaniu pewne więzy"13.

Epifanijny wymiar twarzy uzmysławia, że drugiego nie da się ani do końca opisać, ani wysłowić. Drugiego się doświadcza. To, co niewysławialne i nieredukowalne, objawia się w twarzy innego, a wszelkie dookreślenia w jakiejś mierze by go uprzedmiatawiały. Dlatego, jak pisze Tischner, „epifania twarzy nie przynosi żadnej wiedzy w potocznym sensie tego słowa. Tym, co przynosi, jest inny - inny jako taki, jako prawdomówny"14. Metoda fenomenologiczna jest zatem przydatna tylko w takim znaczeniu, iż naprowadza na doświadczenie, nie jest za to w stanie opisać fenomenu twarzy. Twarz się objawia, a nie przejawia. Jest nośnikiem sensu, a nie przejawem rzeczy. Istota twarzy i sposoby jej doświadczania to dwie różne kwestie, choć nierozłącznie ze sobą związane. Przez doświadczenie twarzy można się jakoś przybliżać do uchwycenia jej istoty, choć próba definiowania twarzy napotyka granice.

Twarz innego indywidualizuje, wskazuje na inność. Trudno uchwycić jakiś stały moment twarzy, bo jej istotą sa pewna "transmisja” wartości (pozytywnych lub negatywnych) oraz swoista "transmisja” sensu. Tisch-

${ }^{13}$ J. Bukowski, Zarys filozofii spotkania, Kraków 1987, s. 155.

${ }^{14}$ J. Tischner, op. cit., s. 22. 
ner zakłada, iż naturalnym miejscem zadomowienia człowieka w świecie są wartości, ale czy z kolei tak samo naturalnym miejscem zadomowienia się wartości jest ludzka twarz? Twarz jest śladem i „stawia nas w krzyżowym punkcie świata. Ten, kto posiada twarz, jest i n n y. Odbiera wiążąca moc czynnościom i projektom czynności, które poprzedzają nasze ruchy w świecie. Nie daje się opisać przy użyciu pojęć, którymi opisujemy rzeczy"15. U Lévinasa twarz jest śladem Absolutu, a imperatyw twarzy narzuca się od razu. U Tischnera zaś doświadczenie twarzy jest gradacyjne i wymaga wysiłku. Aby poznać drugiego, trzeba go spotkać, a spotkać - to „spotkać innego w jego twarzy" ${ }^{\prime 6}$. Dostęp do twarzy jest dramatyczny (a nie radykalnie etyczny jak u Lévinasa), a samo objawienie twarzy spoczywa u źródeł dramatu ${ }^{17} \mathrm{i}$ w jakiś sposób odsyła do pojęcia procesu oraz pojęcia wolności. U Lévinasa dostęp do twarzy innego jest od razu etyczny, bezpośredni i pasywny, u Tischnera zaś ta kwestia pozostaje polemiczna, ponieważ twarz może mieć rozmaite modalności i ma charakter na wskroś aktywny: „twarz nie tylko opowiada o doznawaniu biedy... ona również na biedę odpowiada"18. Los człowieka i jego dzieje rozgrywają się w dramatycznym splocie dobra i zła, czyli horyzontu agatologicznego, który objawia się w każdej relacji i do każdej odsyła. Twarz nie jest do końca uchwytna, a perspektywa dogłębnego poznania pozostaje wciąż otwarta. Twarz w filozofii spotkania staje się „metafora, chcącą uwolnić się od balastu zmysłowości” ${ }^{19}$, a „życie metafory rozgrywa się w ciagłym ruchu pomiędzy tym, co dosłowne, a tym, co czysto metaforyczne [...]. A zatem twarz musi być zarazem konkretna i ogólna, dana w doświadczeniu i objawiająca się w wydarzeniu spotkania, wskazująca na skończoność i odsyłająca do nieskończoności”20.

\section{Twarz jako przedpole rozumienia sensu}

Twarz niejako mieni się różnymi stronami sensu, może skrywać lub odsłaniać, przybliżać do prawdy lub oddalać od niej, prowokować, mylić, kłamać, manipulować, zapraszać, nęcić, intrygować. Dlatego można uchwycić to, co się w twarzy przejawia, tylko w jakimś przybliżeniu. Choć Tischner pisze, iż twarz ,jest miejscem, w którym pojawia się prawda człowieka"21, to

\footnotetext{
${ }^{15}$ Ibidem, s. 25.

${ }^{16}$ Ibidem, s. 25.

${ }^{17}$ Ibidem, s. 25.

${ }^{18}$ Ibidem, s. 63.

${ }^{19}$ D. Kot, Zagadka twarzy, „Ethos” 2016, t. 29, nr 2 (114), s. 45.

${ }^{20}$ Ibidem, s. 48.

${ }^{21}$ J. Tischner, Fenomenologia spotkania, „Analecta Cracoviensia” 1978, 10, s. 73.
} 
jednak pełen wgląd wydaje się nieosiągalny. Istnieje wiele możliwości konstytuowania się twarzy Innego, zatem tylko część lub jaką́s „stronę” sensu twarzy można uchwycić. Być może przez rozmaite modi twarzy nigdy nie mamy dostępu do niej jako takiej, do jej „nagości”, niemniej jakiś przebłysk jej prawdy odsłania się w spotkaniu. Twarz osoby de facto nabiera dalece bardziej złożonych znaczeń w międzyosobowej relacji, niż kiedy jest tylko dla siebie. Tischner jednak nie przejmuje Lévinasowskiej propozycji o radykalnej asymetrii, w której twarz innego jest twardym nakazem etycznym. Przyjmuje perspektywę pragnienia jako warunku możliwości otwarcia spotkania twarzy. Pragnienie wedle Tischnera jest podmiotowym warunkiem doświadczenia twarzy, naprowadzającym na nią i pobudzającym myślenie i wolność, która ostatecznie „w horyzoncie agatologicznym konstytuuje i usprawiedliwia więź odpowiedzialności” ${ }^{22}$. Ostatecznie w filozofii Tischnera gra toczy się o wolność człowieka, a także w jakiejś mierze o jego twarz, czyli o prawdę bycia, gdyż tam, gdzie „prawda jest w niebezpieczeństwie, tam $\mathrm{w}$ niebezpieczeństwie jest również rozum, nauka, racjonalizm i sam człowiek”" samo zaś „słowo "twarz» nie jest ani proste, ani zrozumiałe. Skrywa nieusuwalną tajemnicę. Co więcej, tajemnica ta należy do samej istoty twarzy: twarz odarta przez myślenie z tajemnicy nie jest twarzą"24. Twarz zatem odkrywa pewien horyzont sensu, ale sam sens jest okryty woalem tajemnicy.

Tischner podejmuje wysiłek dookreślenia twarzy przez jej negatywy: zasłonę i maskę, ale w obu jego ujęciach te kategorie są dyskusyjne i nie wyczerpuja analityki twarzy. Zasłonę rozpatruje w aspekcie wstydu i odwołuje się do Jeana-Paula Sartre'a, maskę zaś rozpatruje w kontekście psychologii Antoniego Kępińskiego. Zwraca uwagę na to, iż ani zasłona, ani maska nie mogą zostać uznane za twarz, bo obie są źródłem fałszu: zasłona skrywa twarz, maska natomiast kłamie, „zadaniem maski jest łudzić mnie, zadaniem wstydu jest ukryć"25. Czy rzeczywiście? Obie maja za zadanie jakoś tłumić twarz, pozorować to, czym ona jest. Przez te zabiegi jednak wcale nie muszą odsłaniać zrazu prawdziwości twarzy. U Tischnera sprawa sporna jest to, na ile zasłona i maska rzeczywiście przez negację odsłaniaja bliżej sens twarzy i czy rzeczywiście bez maski objawiamy swą twarz.

Wydaje się przecież, iż istnieją takie momenty wstydu, w których niekoniecznie ujawnia się preferowana przez nas wartość, oraz takie aspekty

\footnotetext{
${ }^{22}$ Idem, Filozofia dramatu, ed. cit., s. 63.

${ }^{23}$ Ibidem, s. 71.

${ }^{24}$ D. Kot, op. cit., s. 45.

${ }^{25}$ J. Tischner, Filozofia dramatu, ed. cit., s. 54.
} 
maski, dzięki którym wcale nie musimy się orientować co do autentyczności twarzy innego. Co więcej, można podać przykłady na sytuację odwrotna, gdy właśnie maska może coś radykalnie ukryć, a wstyd - całkowicie lub czasowo łudzić. Wymiennie mogą łudzić, ukrywać i mamić. Maska daje złudne poczucie bezpieczeństwa, paradoksalnie nie chroni, może być źródłem generowania różnych oszustw, a także komunikować coś, co zdezorientuje odbiorcę. Ponadto relacyjny charakter twarzy i jej negatywów: zasłony i maski generuje kolejne paradoksy w zależności od kontekstu i doświadczenia - Inny zakładający jakiś rodzaj maski może stać się obcy dla drugiego, obcy z kolei objawiający swą twarz może stać się bardziej bliskim dla drugiego, bliski zaś w masce może stawać się coraz bardziej dalekim dla drugiego. Bliski „w” masce może się oddalać, zamykać, udawać, a daleki (obcy) dzięki prawdzie swej twarzy może się przybliżać, zjednywać, otwierać.

Maska wedle Tischnera kłamie, ale gdyby proste było rozszyfrowanie wszystkich jej modalności, dostęp do twarzy byłby absolutny. Stwierdzenie Tischnera o kłamliwej roli maski jest radykalne, ale ma lukę. Istnieje bowiem taka funkcja maski, która zrazu nie kłamie, lecz tylko przyćmiewa blask. Zdaje się, iż masek może być tak wiele, jak wielu jest ludzi. Jest to kategoria mocno zniuansowana, zresztą jak i sama twarz. Należy jednak zgodzić się z Tischnerem, kiedy odnosi on te kwestie do prawdy. Maska bowiem maskuje prawdę, ,stara się stworzyć ułudę będącą przeciwieństwem tego, jak coś naprawdę jest [...]. Między maską a maskowaną prawdą ustala się coś na kształt przeciwieństwa aksjologicznego; wartość negatywna chce się przedstawić jako pozytywna" ${ }^{26}$. Tu ujawnia się radykalny sens maski. Sens umiarkowany odnajdujemy natomiast nieco dalej. Maska nie jest już rozumiana jako negacja prawdy, lecz jako wyostrzenie danej właściwości jako typowej z pozostawieniem na boku innych.

\section{Maska jako negatyw twarzy}

Paradoksalnie jednak twarz jakoś potrzebuje swego przeciwieństwa, by wiedzieć, czym jest. Kontrowersyjne, ale chyba uprawnione w tym miejscu jest stwierdzenie, iż być może gdyby nie istnienie maski, nie wiadomo byłoby, czym jest twarz. I odwrotnie: dzięki twarzy wiemy, czym jest maska. Odsłania się jakiś sens maski jako warunku poznania twarzy: „,spotykając maskę, nie możemy nie pytać o twarz”27. Czy można zatem zrezygnować

\footnotetext{
${ }^{26}$ Ibidem, s. 57.

${ }^{27}$ Ibidem, s. 61.
} 
z maski? Czym ona jest? Chroni twarz czy wystawia ją na opresje? Co tak naprawdę kryje się za maską? Absolut twarzy? Absolut „ja”? Czy można nakładać maski w nieskończoność? Na jaka perspektywę otwiera zamaskowana twarz, a na jaka twarz „czysta”, nieupozorowana? Te i wiele innych pytań utrudniają interpretację, bowiem sam punkt odniesienia (owa „twarz”) jest dość mglisty i tajemniczy. Tischner wskazuje na taki moment spotkania, który sięga głębokich pokładów istnienia drugiego. Kiedy mówi: „Doświadczenie spotkania, ściślej: przeżycie spotkania, wprowadza tego, kto spotyka, w jakąś jedyną w swoim rodzaju, osobistą prawdę spotkanego człowieka. [...] Spotykając, wiem, że inny człowiek jest, że jest wobec mnie takim, jakim jest naprawdę, bez masek i zasłon" ${ }^{28}$. W przytoczonym cytacie jak w soczewce skupiają się jedne z najistotniejszych pojęć filozofii Tischnera i choć u źródeł tak rozumianego wydarzenia spotkania leży dramat, to przebłyskuje tu również nadzieja prawdy i autentyczności, przechodzących jakoś przez twarz drugiego lub bijących wręcz z jego twarzy. Rysuje się wtedy perspektywa wzajemnego poznania, obcowania, rozumienia, a samo spotkanie „wprowadza człowieka w głąb wielkich tajemnic istnienia, gdzie rodzą się pytania o sens i bezsens wszystkiego, co jest”" 29 .

Istotą spotkania wedle Tischnera jest bycie „twarzą w twarz”, czyli specyficzna sytuacja obcowań Ja i Ty, którzy bez zapośredniczeń mogą uczestniczyć we wzajemnym „naprzeciw”. Stając wobec siebie i będąc względem siebie, muszą napotkać twarz drugiego, czyli w jakiś sposób to, kim jest drugi. Przez poznanie twarzy Ja i Ty zbliżają się lub oddalają od siebie, ale właśnie to, co się przez twarz przedostaje, scala ich w spotkaniu albo separuje. W potocznym sensie relacja bycia „twarzą w twarz” niejednokrotnie nastręcza podmiotom trudności, należy bowiem spełnić co najmniej kilka warunków umożliwiających rozmowę. Takie bycie „twarzą w twarz” prowokuje do głębszej odsłony siebie, swoich pragnień, sposobu myślenia, ale też do patrzenia drugiemu w oczy, skierowania uwagi itp., co wymaga o wiele więcej wysiłku i odwagi niż w przypadku zapośredniczeń. To, co interesuje Tischnera, wykracza poza potoczny kontekst. Być „twarzą w twarz” to zaryzykować jakoś swoim istnieniem, to być w prawdzie, nawet za cenę odrzucenia, to w sposób autentyczny być i jakoś zademonstrować ową prawdę, lecz w sposób nie tyle intencjonalny, ile dialogiczny. Dramatyczny sens twarzy polega jednakże na nieusuwalnej możliwości skrywania tej prawdy, tłamszenia jej lub wręcz zakłamania pod postaciąjakiejś zasłony lub maski. Dlatego napotkanie twarzy Innego zawsze niesie pewne novum, które może być obietnica przybliżania się do prawdy albo niepewnością oddalania się od niej.

${ }^{28}$ Idem, Spotkanie w horyzoncie zła, „Analecta Cracoviensia” 1981, 13, s. 85.

${ }^{29}$ Idem, Bezdroże spotkań, „Analecta Cracoviensia” 1980, 12, s. 142. 


\section{"Mowa" twarzy a inność Innego}

Twarz Innego jakoś „mówi”, ale to, co mówi, dlaczego i w jakim celu, objawiają inne funkcje mowy ${ }^{30}$. To, że twarz coś „komunikuje”, wyraża nie tylko to, że człowiek jest, lecz także istnieje w określony sposób, odwołując się do danych wartości. „Język” i „mowa” twarzy są czymś innym niż rozmowa jako sposób na wyrażenie myśli, ponieważ twarz wcale nie musi od razu wyjawiać prawdy bycia podmiotu, a nawet może dawać sprzeczne komunikaty i przez to mamić odbiorcę. Komunikaty „wypisane” na twarzy mogą dawać jakieś przeczucie co do prawdziwości lub fałszywości podmiotu, ale należy podkreślić, iż dany podmiot w zależności od tego, kim jest i chce być dla drugiego w relacji, pozostaje na poziomie intencjonalnym albo dialogicznym. Dla Tischnera zaś tylko ten drugi „,personifikuje”, intencjonalny natomiast „uprzedmiatawia” ${ }^{31}$.

Tischner dostrzega paradoksalność Innego: on nie jest nigdy tak inny, by nie był zarazem podobny, i na odwrót, nie jest nigdy tak podobny, by nie był zarazem inny: jest inny w podobieństwie i podobny w inności ${ }^{32}$. W analityce twarzy powyższe stwierdzenie Tischnera ma siłę wiążącą Ja i Ty. Skoro Inny wraz ze swoją innością wydobywa na jaw inność drugiego, to również przez fenomen twarzy dokonuje się specyficzna wzajemność, która nie znosi różnic. Przeciwieństwa i podobieństwa moga płynnie się wymieniać w stronę narastającej inności albo narastającej takoż samości. Tischner twierdzi, iż z przeciwieństwa „wyłania się napięcie, na którym rośnie zaciekawienie i zdumienie, ale także niepokój, lęk, gotowość do ucieczki. Z kolei doświadczenie podobieństwa i narastającej takoż samości rodzi świadomość «znajomości» i spokój. Niepokój i pokój przeplatają się i krzyżują. Inny coś obiecuje i zarazem czegoś odmawia” ${ }^{33}$. Na osi spotkania twarzy Ja i Ty ,jest dramaturgia wypełniona całym ciągiem mniejszych i większych wydarzeń,

${ }^{30} \mathrm{~W}$ tym kontekście warto odwołać się do tekstu Marka Drwięgi Fenomenologia i twarz innego. Kontrowersje wokót Lévinasa, w którym autor ukazuje rys nowej fenomenologii, rozpoczętej Lévinasowską krytyką Husserla, prowadzącej do dyskusji nad nowym pojmowaniem samego fenomenu wśród różnych współczesnych stanowisk fenomenologicznych. Na przykładzie fenomenu twarzy Drwięga przywołuje interpretację Jeana-Luca Mariona, podkreślając m.in. paradoksalny milczący charakter mowy twarzy. W Marionowskiej interpretacji Lévinasa twarz innego mówi, milcząc; należy do fenomenów przesyconych, tzn. takich, które wymykają się jednoznaczności i widzialności. Twarz jest naddatkiem, który się narzuca, nakazując wzięcie odpowiedzialności za „nie zabijaj”, ale, jak interpretuje Drwięga, „wraz z «nie zabijaj» wyłania różnorodność niekończących się możliwości znaczeń, mniej lub bardziej tymczasowych, a zatem jako fenomen nie pozwala się ukonstytuować, to raczej twarz narzuca nam swój fenomen” („Logos i Ethos” 2019, 1(49), s. 82).

${ }^{31}$ J. Tischner, Inny. Eseje o spotkaniu, Kraków 2017, s. 9.

${ }^{32}$ Por. ibidem, s. 11.

${ }^{33}$ Ibidem, s. 14. 
w których daje się wychwycić jakaś wychodząca poza jednostkowe życiorysy wspólnota losu" ${ }^{4}$. Oznaczałoby to, iż twarz z jednej strony nie jest czymś stałym, lecz wciąż na nowo wydarzającym się w obliczu drugiego, a zarazem też nie czymś abstrakcyjnym, czego nie da się poznawczo uchwycić.

Według Tischnera istnieje moment, który umożliwia uchwycenie wewnętrznej indywidualności innego. Ów moment wymaga zatrzymania się, koncentracji na drugim, uważności i wejścia na poziom wewnętrzny, na którym rozgrywa się sposób „trawienia świata” przez innego. Tischner nazywa to „indywidualnym skrętem świadomości”, który ma każdy człowiek, a przez spotkanie oba "skręty” ścierają się w dialektycznym i dramatycznym ruchu obcowań. Tam też objawiają się w dany sposób twarze Ja i Ty, które albo zbliżają się do siebie, albo oddalaja; objawiają prawdę Ja i Ty albo skrywaja prawdę któregoś lub obu. Twarz Innego zaprasza, a nawet wzywa do zmiany, a wyzwanie dla Tischnera oznacza przede wszystkim to, abym stał się innym dla siebie samego. W przeciwnym razie twarz drugiego pozostanie w oddaleniu, a dostęp do niej będzie polegał jedynie na fizykalnym oglądzie jej zewnętrznych warstw. Aby dotrzeć do twarzy drugiego, należy aktywnie przenieść akcent punktu widzenia z siebie na innego, dokonać wyjścia, „zatopienia”, a nawet „obumarcia dla siebie”, co w efekcie przemienia całą relację w bycie dla Innego. Nie ma jednak gwarancji na pełne poznanie, ponieważ Inny niesie w sobie ładunek nieprzewidywalnych wyborów, a głębia, którą ma, „ukazuje się i skrywa jednocześnie” ${ }^{35}$. Można wyprowadzić stąd wniosek, iż sama twarz wraz z jej wielopoziomowością ogniskuje w sobie wiele paradoksalnych momentów i w zależności od kontekstu może coraz bardziej naprowadzać drugiego na prawdę Innego lub od niej oddalać. Tischner jednakże skłania się do stwierdzenia, iż pomimo istnienia wielu wątpliwości „nie ma lepszej drogi do wnętrza Innego jak droga poprzez wyraz. Choć każdy wyraz jest nosicielem cząstkowej prawdy o człowieku, to jednak z prawd cząstkowych daje się zbudować prawda fundamentalna dotycząca całości”36.

\section{Podsumowanie}

Podsumowując powyższe syntetyczne ujęcie twarzy w koncepcji Tischnera, należy podkreślić, iż nie tylko Ty innego jest w niej napotkane, rozpoznane i objawione, lecz także istnieje pewne dotknięcie prawdy jego bycia, jego osobowej wartości. Owo dotknięcie nie zawsze musi być konkretne, dokładne

\footnotetext{
${ }^{34}$ Ibidem, s. 12.

${ }^{35}$ Ibidem, s. 31.

${ }^{36}$ Ibidem, s. 31.
} 
i jasne, ale Tischner z pewnością opowiada się za realnym doświadczeniem tu i teraz, w którym Ty drugiego daje o sobie znać i w wydarzeniu spotkania jest kimś wyjątkowym, kto niesie swoją biografię, los, biedę i nadzieje.

Dlatego mimo skomplikowanego charakteru twarzy i jej rozmaitych modi istnieje coś, co naprowadza coraz bardziej na tożsamość Ty. Poprzez obcowanie z drugim, bycie nie tylko z nim, ku niemu, lecz także dla niego, tworzy się perspektywę coraz pełniejszego objawiania się twarzy Ja i Ty. Od wolności Ja i Ty będzie zależało nie tylko to, na ile ich twarze wzajemnie odsłonią blask prawdy (nawet trudnej i bolesnej), a na ile trwanie w iluzji maski umożliwi im jakieś pozorne bycie dla siebie.

Czy jednak maska i zasłona jakoś przybliżają do zdefiniowania i napotkania twarzy jako takiej, pozostaje kwestią otwartą. Z pewnością kategoria dramatyczności naprowadza na obie i pluralizuje problematykę człowieka oraz jego tożsamości. Być może sens odpowiedzi na podobne pytania zawiera się w samym ich stawianiu. Odpowiedzi zaś w zależności od napotkanej i wydarzającej się relacji będą zawsze inne, niedające się do końca uchwycić poznawczo.

\section{BIBLIOGRAFIA}

Buber M., Ja i Ty. Wybór pism filozoficznych, przeł. J. Doktór, Warszawa 1992.

Bukowski J., Zarys filozofii spotkania, Kraków 1987.

Drwięga M., Fenomenologia i twarz innego. Kontrowersje wokót Lévinasa, „Logos i Ethos” 2019, 1(49).

Hernas A., Czas i obecność, Kraków 2005.

Kot D., Zagadka twarzy, „Ethos” 2016, t. 29, nr 2 (114).

Lévinas E., Etyka i Nieskończony, Kraków 1985.

Tischner J., Bezdroże spotkań, „Analecta Cracoviensia” 1980, 12.

Tischner J., Fenomenologia spotkania, „Analecta Cracoviensia” 1978, 10.

Tischner J., Filozofia dramatu, Kraków 2006.

Tischner J., Inny. Eseje o spotkaniu, Kraków 2017.

Tischner J., Spotkanie w horyzoncie zła, „Analecta Cracoviensia” 1981, 12.

Wróbel-Best J., W kręgu (własnych) stów Emmanuela Lévinasa. Rozmowa na temat ludzkiej egzystencji, Houston 2016.

Inga Mizdrak - dr nauk hum., Uniwersytet Ekonomiczny w Krakowie. Filozof, zajmuje się filozofią człowieka, etyka, filozofią dialogu. Członkini Polskiego Towarzystwa Filozoficznego oraz Polskiego Towarzystwa Etycznego. Autorka publikacji z antropologii filozoficznej i etyki. Ostatnio opublikowała pozycję $O$ wydarzeniu spotkania w ujęciu Józefa Tischnera ([w:] O spotkaniach w pracy. Szkice psychologiczne, red. Z. Ratajczak, A. Gałuszka, Warszawa 2020, s. 54-70) i artykuł Sfera „pomiędzy” jako relacja istnień,

\begin{tabular}{l|r} 
Inga Mizdrak & $\mathbf{2 7 0}$ \\
&
\end{tabular}


węzet dramatyczny oraz oś uwspólnotowienia (,Studia Humanistyczne AGH” 2019, t. 18/2, s. 129-141). ORCID: 0000-0003-1689-2392. Adres e-mail: <minga9@gmail.com>.

Inga Mizdrak - PhD in humanities, Cracow University of Economics, philosopher, deals with philosophy of the human person, ethics, and the philosophy of dialogue. Member of the Polish Philosophical Society and the Polish Ethical Society. Author of publications on philosophical anthropology and ethics, recently published $O$ wydarzeniu spotkania w ujęciu Józefa Tischnera ([in:] O spotkaniach w pracy. Szkice psychologiczne (On an Encounter from Józef Tischner's Perspective ([in:] On Workplace Encounters. Psychological sketches), ed. Z. Ratajczak, A. Gałuszka, Warszawa 2020, p. 54-70) and the article Sfera „pomiędzy” jako relacja istnien, węzet dramatyczny oraz oś uwspólnotowienia (The Sphere "Between" as a relation of Existences, the Dramatic Node and the Axis of Communitarisation) ("Studia Humanistyczne AGH" 2019, vol. 18/2, p. 129-141). ORCID: 0000-0003-1689-2392. E-mail address: <minga9@gmail.com>. 
